\title{
HUBUNGAN SANITASI RUMAH DENGAN KEJADIAN PENYAKIT TUBERKULOSIS (TB) DI KECAMATAN KUTA
}

\author{
I Made Mudana ${ }^{1 *}$, Nyoman Adiputra ${ }^{2)}$, I.B.G. Pujaastawa ${ }^{3)}$ \\ ${ }^{1)}$ Dinas Kesehatan Kabupaten Badung \\ ${ }^{2}$ Fakultas Kedokteran Universitas Udayana \\ ${ }^{3}$ Program Studi Magister (S2) Kajian Budaya Universitas Udayana \\ "Email: mmudana84@yahoo.com
}

\begin{abstract}
One of the endemic infectious diseases occured in the community is tuberculosis (TB). The World Health Organization (WHO) estimated about one third of the world's population has been infected by the bacteria mycobacterium tuberculosis. Badung regency as one of the districts in the province of Bali also having cases of tuberculosis. From the report Badung Health Agency in 2015 was recorded 275 TB patients. From 6 districts in Badung district, subdistrict of Kuta occupy the highest number of cases recorded 100 patients. tuberculosis is closely related to homes sanitation that do not meet health requirements. The purpose of this study was to determine the relationship of home sanitation with disease incidence of tuberculosis in the district of Kuta. Based on the type of research is observational analytic, design research is a case control studies linking ie risk factors. (Home sanitation) with TB disease events, by comparing the case group and the control group. The population in this study are patients with TB BTA (+) were treated working area Puskesmas Kuta I and Puskesmas Kuta II sanitation as well as his home. The number of samples in this study was 60 consisting of the case group and the control group. How sampling is the total population of TB patients in the last 3 months of 2015 as well as sanitary home. Data collected from interviews, observations and measurements and then analyzed using chi square and followed by multiple logistic regression test. From the statistic test bivariate home sanitation with tuberculosis disease incidence 6 variables showed that: (1) lighting $\mathrm{p}=0,00(\mathrm{p}<0,05) \mathrm{OR}=21,(2)$ humidity $\mathrm{p}=0,00(\mathrm{p}<0,05) \mathrm{OR}=21,36,(3)$ ventilation $\mathrm{p}=$ $0,00(p<0,05) \mathrm{OR}=11,(4)$ the walls of the house $\mathrm{p}=0,00(\mathrm{p}<0,05) \mathrm{OR}=8,64$, (5) density residential home $\mathrm{p}$ $=0,00(p<0,05) \mathrm{OR}=16,43$ and $(6)$ house floor $\mathrm{p}=0,22(\mathrm{p}>0,05) \mathrm{OR}=2,143$. To determine the relationship of all independent variables simultaneously multivariate analysis with multiple logistic regression test. Based on the results obtained that there are three independent variables significantly related $(p<0,05)$ with the dependent variable is the humidity $(\mathrm{OR}=19,158,95 \% \mathrm{CI} 3,171-115,751)$, ventilation $(\mathrm{OR}=6,408,95 \% \mathrm{CI}$ $=1,199$ to 34,236$)$, residential density $(\mathrm{OR}=13,342,95 \% \mathrm{CI}=2,261-78,733)$. Probability of people who occupy the house with sanitation (Humidity, Ventilation and Residential density) in the district of Kuta to contract tuberculosis (TB) is $97,08 \%$. Based on these results, we can conclude that from the test bivariate (6 variables) are: lighting, humidity, ventilation, walls of houses, residential density and house floor associated with the incidence of tuberculosis in the district of Kuta. While the advice may be given to: (1). people who live in the district of Kuta in order to build or occupy a dwelling house to take into account the standard of sanitation and healthy home. (2). Government / agencies in order to provide guidance to the public in order to build houses of spatial attention and care homes that meet health requirements so that people who lived in the house to feel safe, comfortable, and avoid the disease especially those stemming from poor sanitation home.
\end{abstract}

Keywords: Sanitation, Home, Disease, Tuberculosis (TB)

\section{PENDAHULUAN}

Salah satu penyakit menular yang masih endemis terjadi di masyarakat adalah penyakit tuberkulosis (TB). Menurut World Health Organization (WHO) diperkirakan sekitar sepertiga penduduk dunia telah terinfeksi oleh kuman mycobacterium tuberculosis, Pada tahun 1995 diperkirakan terdapat 9 juta pasien TB paru dan 3 juta kematian akibat TB di seluruh dunia.
Diperkirakan 95\% kasus TB dan 98\% kematian akibat TB di dunia terjadi pada negara-negara berkembang (Kemenkes RI, 2011).

Sumber penularannya adalah pasien TB BTA positif, pada waktu batuk atau bersin pasien menyebarkan kuman ke udara dalam bentuk percikan dahak (droplet nuclei). Percikan dapat bertahan selama beberapa jam dalam keadaan yang gelap dan lembab. Daya penularan seorang pasien ditentukan oleh banyaknya kuman yang dikeluarkan 
dari parunya. Makin tinggi derajat kepositifan hasil pemeriksaan dahak, makin menular pasien tersebut. Faktor yang memungkinkan seseorang terpajan kuman TB ditentukan oleh konsentrasi percikan dalam udara dan lamanya menghirup udara tersebut. (Kemenkes RI, 2011).

Sejak lama telah diketahui bahwa timbulnya penyakit tidak hanya disebabkan oleh kuman saja, tetapi faktor lingkungan sangat berpengaruh terhadap timbulnya suatu penyakit. Penyebaran penyakit tuberkulosis erat kaitannya dengan sanitasi lingkungan tempat tinggal seperti ; Pencahayaan, kelembaban, suhu, ventilasi, kepadatan hunian, dinding rumah dan lantai rumah. Faktor kesehatan lingkungan rumah yang berhubungan dengan kejadian TB Paru adalah pencahayaan $(\mathrm{OR}=4,214)$, ventilasi $(\mathrm{OR}=4,932)$, kelembaban $(\mathrm{OR}=2,571)$, suhu udara $(\mathrm{OR}=2,674)$, jenis lantai $(\mathrm{OR}=1,626)$, kepadatan hunian $(\mathrm{OR}=0,820)$, status gizi $(\mathrm{OR}=$ 2,737), (Fatimah, 2008).

Kabupaten Badung sebagai salah satu destinasi pariwisata internasional di samping memperoleh manfaat ekonomi yang signifikan dari penerimaan pajak hotel dan restoran (PHR), tetapi juga dihadapkan dengan masalah kian meningkatnya arus urbanisasi dan migrasi penduduk yang disebabkan oleh berkembangnya sektor kepariwisataan di daerah ini. Fenomena ini membawa sejumlah dampak, di antaranya semakin padatnya permukiman penduduk di daerah-daerah kawasan pariwisata, terutama di Kawasan Pariwisata Kuta. Meskipun di kawasan ini terdapat berbagai fasilitas pariwisata bertaraf internasional, namun di sisi lain juga ditemui adanya sejumlah permukiman penduduk dengan tingkat kepadatan yang tinggi dan terkesan kumuh. Kenyataan ini dikhawatirkan berpotensi terjangkitnya berbagai penyakit, termasuk penyakit tuberkulosis.

Berdasarkan laporan Dinas Kesehatan Kabupaten Badung tentang penyakit TB dalam 3 tahun terakhir yaitu tahun (2013- 2015), diketahui bahwa jumlah kasus tuberkulosis pada tahun 2013 tercatat 128 orang pada tahun 2014 tercatat 170 orang dan tahun 2015 tercatat 275 orang (Dinas Kesehatan Badung, 2014, 2015, 2016). Jumlah kasus tuberkulosis tersebut tersebar di masing - masing puskesmas yang berada di wilayah Kabupaten Badung. Jumlah kasus penderita TB tertinggi terdapat di Kecamayan Kuta yang mewilayahi Puskesmas Kuta I tercatat 80 kasus dan Puskesmas Kuta II tercatat 20 kasus, sehingga total di Kecamatan Kuta mencapai 100 kasus.

Tingginya jumlah kasus penderita tuberkulosis di Kecamatan Kuta merupakan fenomena yang cukup menarik untuk dikaji, mengingat wilayah ini tergolong kawasan pariwisata yang cukup populer baik di kalangan wisatawan nusantara maupun mancanegara. Masalah tersebut akan dicoba dijelaskan dengan menjawab pertanyaan penelitian yang diformulasikan sebagai berikut : 1 . Bagaimanakah hubungan sanitasi rumah yang meliputi pencahayaan, kelembaban, suhu, ventilasi, kepadatan hunian, dinding rumah dan lantai rumah dengan kejadian penyakit tuberkulosis di Kecamatan Kuta? 2. Seberapa jauh hubungan variabel sanitasi rumah yang meliputi pencahayaan, kelembaban, suhu, ventilasi, dinding rumah, kepadatan hunian, dan lantai rumah dengan kejadian penyakit tuberkulosis di Kecamatan Kuta?

\section{METODOLOGI}

Berdasarkan jenisnya penelitian ini termasuk penelitian analitik observasional, untuk menganalisis faktor sanitasi rumah terhadap kejadian penyakit tuberkulosis paru di Kecamatan Kuta . Rancang bangun penelitian ini termasuk case control yaitu penelitian yang menghubungkan faktor risiko atau variabel bebas (sanitasi rumah) dengan kejadian penyakit tuberkulosis dengan cara membandingkan kelompok kasus (penderita tuberkulosis paru) dan kelompok kontrol (bukan penderita). Jumlah sampel yang diambil sebanyak 60 orang yang terdiri dari 30 kasus dan 30 kontrol. Data yang diperoleh diolah dan dianalisis dengan menggunakan komputer dengan program SPSS . Sedangkan untuk analisis data yang dilakukan meliputi analisis univariat, bivariat dan multivariat (Yasril, 2009).

\section{HASIL DAN PEMBAHASAN}

\subsection{Gambaran Umum Lokasi Penelitian}

Kecamatan Kuta secara administrasi terdiri dari 5 desa/kelurahan dengan 33 banjar dengan luas wilayah $17,52 \mathrm{~km}^{2}$. Secara geografis Kecamatan Kuta terletak antara 08 $43^{\prime} 32.6^{\prime \prime}$ Lintang Selatan dan $115^{0} 10^{\prime} 39.2^{\prime \prime}$ Bujur Timur. Wilayah Kecamatan Kuta tergolong wilayah pesisir dengan letak ketinggian terletak $27 \mathrm{~m}$ di atas permukaan laut (Badung dalam Angka, 2015). Di wilayah Kecamatan Kuta terdapat 2 puskesmas induk yang dimenfaatkan oleh masyarakat selain rumah sakit dan klinik yaitu Puskesmas Kuta I dan Puskesmas Kuta II. Peta Kecamatan Kuta dapat dilihat pada Gambar 1.
3.2 Distribusi Frekuensi Kondisi Pencahayaan, Kelembaban, Suhu, Ventilasi, Dinding Rumah, Kepadatan Hunian dan Lantai Rumah 


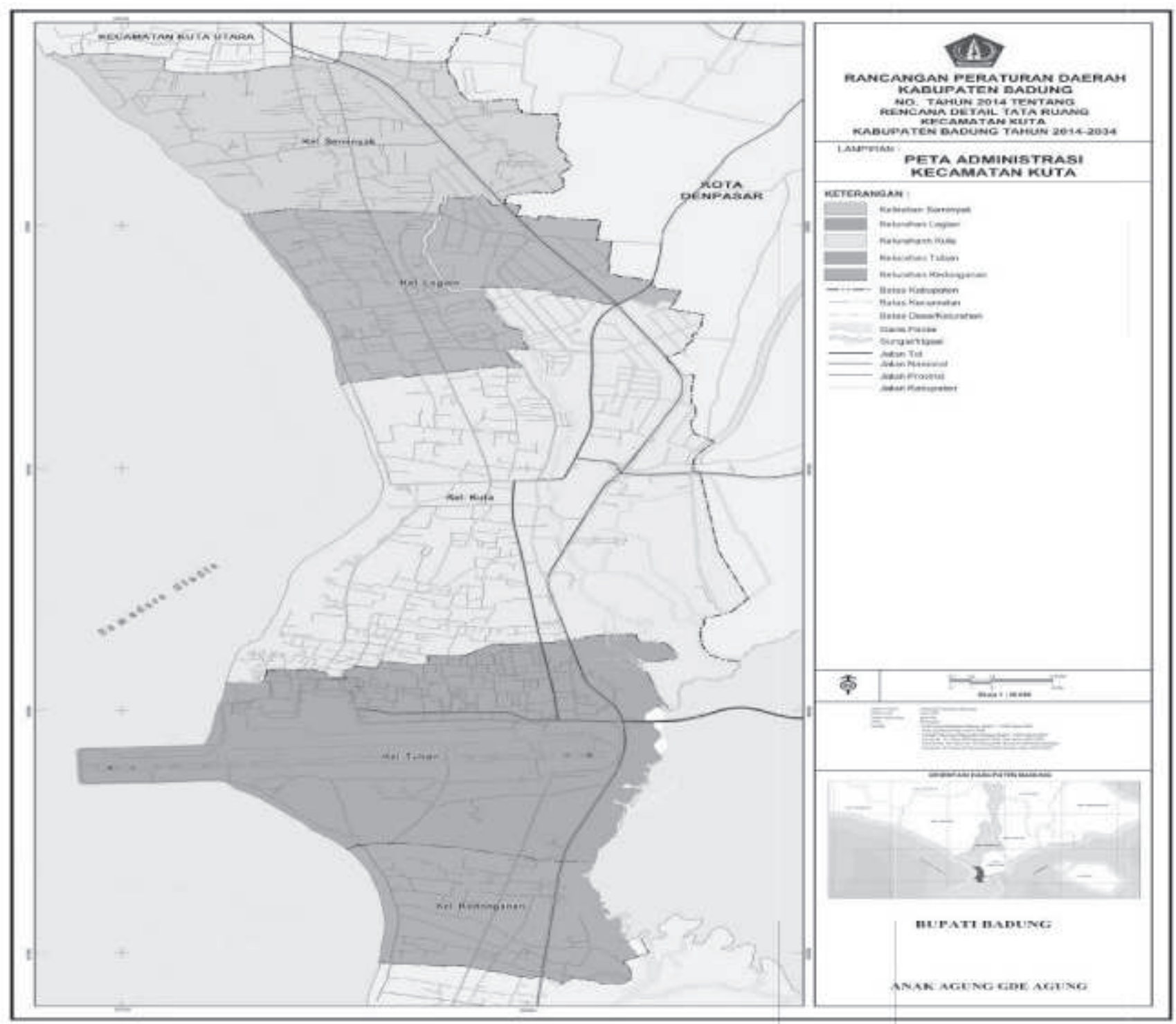

Gambar .1. Peta Kecamatan Kuta

Tabel 1. Hasil Pengukuran Sanitasi Rumah di Kecamatan Kuta

\begin{tabular}{|c|c|c|}
\hline Variabel Penelitian & Jumlah(n=60) & Persentase \\
\hline \multicolumn{3}{|l|}{ Pencahayaan } \\
\hline Tidak memenuhi syarat & 24 & 40 \\
\hline Memenuhi syarat & 36 & 60 \\
\hline \multicolumn{3}{|l|}{ Kelembaban } \\
\hline Tidak memenuhi syarat & 27 & 45 \\
\hline Memenuhi syarat & 33 & 55 \\
\hline \multicolumn{3}{|l|}{ Suhu } \\
\hline Tidak memenuhi syarat & 0 & 0 \\
\hline Memenuhi syarat & 60 & 100 \\
\hline \multicolumn{3}{|l|}{ Ventilasi } \\
\hline Tidak memenuhi syarat & 32 & 53,3 \\
\hline Memenuhi syarat & 28 & 46,7 \\
\hline \multicolumn{3}{|l|}{ Dinding rumah } \\
\hline Tidak memenuhi syarat & 24 & 40 \\
\hline Memenuhi syarat & 36 & 60 \\
\hline \multicolumn{3}{|l|}{ Kepadatan hunian } \\
\hline Tidak memenuhi syarat & 32 & 53,3 \\
\hline Memenuhi syarat & 28 & 46,7 \\
\hline \multicolumn{3}{|l|}{ Lantai rumah } \\
\hline Tidak memenuhi syarat & 14 & 23,3 \\
\hline Memenuhi syarat & 46 & 76,7 \\
\hline
\end{tabular}

\subsection{Hubungan Pencahayaan dengan Kejadian Penyakit TB \\ Hasil yang didapatkan dari analisis data} penelitian terhadap variable pencahayaan dengan kejadian penyakit TB adalah seperti pada tabel 2.

Berdasarkan Tabel 2, menunjukkan bahwa 70 \% kasus penghuni rumah dengan pencahayaan yang tidak memenuhi syarat kesehatan dan $30 \%$ penghuni rumah dengan pencahayaan yang memenuhi syarat kesehatan menunjukkan bahwa secara statistik terdapat hubungan yang bermakna pencahayaan rumah terhadap kejadian penyakit TB. $(p<0,05)$ dengan nilai odd ratio 21 . Hasil penelitian ini sesuai dengan hasil penelitian Ahmad dan Sulistyorini (2005) yang menemukan bahwa penerangan alami memperoleh nilai $\mathrm{p}=0,047(\mathrm{p}<0,05)$, hasil penelitian Dewi, (2012) yang menemukan bahwa pencahayaa alami memperoleh nilai $p=0,003(p<0,05)$. Hal ini berarti pencahayaan mempunyai pengaruh terhadap kejadian penyakit TB paru. 
Tabel 2. Hubungan Pencahayaan Dengan Tingkat Kejadian Penyakit TB

\begin{tabular}{|c|c|c|c|c|c|c|}
\hline \multirow{3}{*}{ Pencahayaan } & \multicolumn{4}{|c|}{ Kejadian Penyakit TB } & \multirow{3}{*}{ Odd Ratio (OR) } & \multirow{3}{*}{$P$} \\
\hline & \multicolumn{2}{|c|}{ Kasus } & \multicolumn{2}{|c|}{ Kontrol } & & \\
\hline & $\mathbf{F}$ & $\%$ & $\mathbf{F}$ & $\%$ & & \\
\hline Tidak memenuhi syarat & 21 & 70 & 3 & 10 & 21 & 0,00 \\
\hline Memenuhi syarat & 9 & 30 & 27 & 90 & & \\
\hline Total & 30 & 100 & 30 & 100 & & \\
\hline
\end{tabular}

\subsection{Hubungan Kelembaban dengan Kejadian Penyakit TB}

Berdasarkan Tabel 3, menunjukkan bahwa 76,7 \% kasus penghuni rumah dengan kelembaban yang tidak memenuhi syarat kesehatan dan 23,3\% penghuni rumah yang memenuhi syarat kesehatan. Secara statistik terdapat hubungan yang bermakna antara kondisi kelembaban rumah dengan kejadian TB Paru $(\mathrm{p}<0,05)$ dengan nilai odd ratio 21,36, Hal ini sesuai dengan hasil penelitian Maryani (2012) yang dilakukan di Kelurahan Bandarharjo Kota Semarang, bahwa kelembaban kamar memperoleh nilai sig $p=0,000(p<0,05)$. Hasil yang sesuai juga diperoleh dari hasil penelitian Nindya dan Sulistyorini (2005) bahwa kelembaban ruangan berpengaruh terhadap ISPA pada balita. Hasil penelitian Sujana, dkk (2013) juga diperoleh kelembaban ruangan mempunyai pengaruh terhadap kejadian penyakit TB paru dengan nilai $p=0,00$ $(\mathrm{p}<0,05)$.

\subsection{Hubungan Suhu dengan Kejadian Penyakit TB}

Berdasarkan Tabel.4, terlihat bahwa suhu tidak berpengaruh terhadap kejadian TB Paru dalam penelitian ini. Rumah yang sehat harus mempunyai

Tabel 3. Hubungan Kelembaban Dengan Tingkat Kejadian Penyakit TB

\begin{tabular}{|c|c|c|c|c|c|c|}
\hline \multirow{3}{*}{ Kelembaban } & \multicolumn{4}{|c|}{ Kejadian Penyakit TB } & \multirow{3}{*}{ Odd Ratio (OR) } & \multirow{3}{*}{$\mathbf{P}$} \\
\hline & \multicolumn{2}{|c|}{ Kasus } & \multicolumn{2}{|c|}{ Kontrol } & & \\
\hline & $\mathbf{F}$ & $\%$ & $\mathbf{F}$ & $\%$ & & \\
\hline Tidak memenuhi syarat & 23 & 76,7 & 4 & 13,3 & 21,36 & 0,00 \\
\hline Memenuhi syarat & 7 & 23,3 & 26 & 86,7 & & \\
\hline Total & 30 & 100 & 30 & 100 & & \\
\hline
\end{tabular}

Tabel 4. Hubungan Suhu dengan Tingkat Kejadian Penyakit TB

\begin{tabular}{lccccc}
\hline \multirow{2}{*}{ Suhu } & \multicolumn{3}{c}{ Kejadian Penyakit TB } & Odd Ratio (OR) & P \\
\cline { 2 - 5 } & \multicolumn{3}{c}{ Kasus } & & \multicolumn{2}{c}{ Kontrol } \\
\cline { 2 - 5 } & $\mathrm{F}$ & $\%$ & $\mathrm{~F}$ & $\%$ \\
\hline Tidak memenuhi syarat & 0 & 0 & 0 & 0 \\
Memenuhi syarat & 30 & 100 & 30 & 100 \\
Total & 30 & 100 & 30 & 100 \\
\hline
\end{tabular}

Tabel 5. Hubungan Ventilasi dengan Tingkat Kejadian Penyakit TB

\begin{tabular}{|c|c|c|c|c|c|c|}
\hline \multirow{3}{*}{ Ventilasi } & \multicolumn{4}{|c|}{ Kejadian Penyakit TB } & \multirow{3}{*}{ Odd Ratio (OR) } & \multirow{3}{*}{$\mathbf{P}$} \\
\hline & \multicolumn{2}{|c|}{ Kasus } & \multicolumn{2}{|c|}{ Kontrol } & & \\
\hline & $F$ & $\%$ & $F$ & $\%$ & & \\
\hline Tidak memenuhi syarat & 24 & 80 & 8 & 26,7 & 11 & 0,00 \\
\hline Memenuhi syarat & 6 & 20 & 22 & 73,3 & & \\
\hline Total & 30 & 100 & 30 & 100 & & \\
\hline
\end{tabular}


suhu yang diatur sedemikian rupa sehingga suhu badan dapat dipertahankan. Jadi suhu dalam ruangan harus dapat diciptakan sedemikian rupa sehingga tubuh tidak terlalu banyak kehilangan panas atau sebaliknya tubuh tidak sampai kepanasan (Azwar, 1996).

\subsection{Hubungan Ventilasi dengan Kejadian Penyakit TB}

Berdasarkan Tabel 5, menunjukkan bahwa 80\% kasus penghuni rumah dengan ventilasi rumah yang tidak memenuhi syarat kesehatan dan hanya $20 \%$ yang memenuhi syarat kesehatan. Secara statistik terdapat hubungan yang bermakna antara kondisi ventilasi dengan kejadian penyakit TB $(\mathrm{p}<0,05)$ dengan nilai odd ratio 11 . Ventilasi rumah mempunyai fungsi (Azwar, 1999). Fungsi pertama adalah untuk menjaga agar aliran udara di dalam rumah tersebut tetap segar. Hal ini berarti keseimbangan $\mathrm{O}_{2}$ yang diperlukan oleh penghuni rumah tersebut tetap terjaga. Kurangnya ventilasi akan menyebabkan kurangnya $\mathrm{O}_{2}$ di dalam rumah yang berarti kadar $\mathrm{CO}_{2}$ yang bersifat racun bagi penghuninya menjadi meningkat.

\subsection{Hubungan Dinding Rumah dengan Kejadian Penyakit TB}

Berdasarkan Tabel 6, menunjukkan bahwa 63,3 $\%$ untuk kasus penghuni rumah dengan didnding rumah yang tidak memenuhi syarat kesehatan dan $36,7 \%$ yang memenuhi syarat kesehatan. Secara statistik terdapat hubungan yang bermakna antara kualitas dinding rumah dengan kemungkinan terjadinya TB $(\mathrm{p}<0,05)$ dengan nilai odd ratio 8,64. Ini berarti responden memiliki rumah tidak memenuhi persyaratan dinding rumah memiliki kemungkinan 8,64 kali lebih besar terkena penyakit TB dibandingkan dengan responden yang memenuhi persyaratan dinding rumah.

\subsection{Hubungan Kepadatan Hunian dengan Kejadian Penyakit TB}

Berdasarkan Tabel 7, menunjukkan bahwa 83,3 $\%$ kasus penghuni rumah dengan kepadatan hunian yang tidak memenuhi syarat kesehatan dan 16,7\% kasus dengan kepadatan hunian yang memenuhi syarat kesehatan. Secara statistik terdapat hubungan yang bermakna antara kepadatan hunian dengan kejadian penyakit TB $(\mathrm{p}<0,05)$ dengan nilai odd rationya 16,43 . Ini berarti responden yang memiliki rumah tidak memenuhi persyaratan kepadatan hunian memiliki kemungkinan 16,43 kali lebih besar untuk terkena penyakit TB dibandingkan dengan responden yang memiliki rumah memenuhi persyaratan kepadatan hunian Sesuai dengan hasil penelitian yang dilakukan oleh Sugiharto (2004), yang menemukan bahwa adanya hubungan yang bermakna antara kepadatan hunian dengan kejadian TB paru dengan nilai $\mathrm{OR}=2,716$, sesuai pula hasil penelitian oleh Wiasa (2009) bahwa ada hubungan yang bermakna antara kepadatan hunian dengan kejadian penyakit dengan nilai $\mathrm{OR}=11,76$.

Tabel 6. Hubungan Dinding Rumah dengan Tingkat Kejadian Penyakit TB

\begin{tabular}{|c|c|c|c|c|c|c|}
\hline \multirow{3}{*}{ Dinding rumah } & \multicolumn{4}{|c|}{ Kejadian Penyakit TB } & \multirow{3}{*}{ Odd Ratio (OR) } & \multirow{3}{*}{$\mathbf{P}$} \\
\hline & \multicolumn{2}{|c|}{ Kasus } & \multicolumn{2}{|c|}{ Kontrol } & & \\
\hline & $F$ & $\%$ & $F$ & $\%$ & & \\
\hline Tidak memenuhi syarat & 19 & 63,3 & 5 & 16,7 & 8,64 & 0,00 \\
\hline Memenuhi syarat & 11 & 36,7 & 25 & 83,3 & & \\
\hline Total & 30 & 100 & 30 & 100 & & \\
\hline
\end{tabular}

Tabel 7. Hubungan Kepadatan Hunian dengan Tingkat Kejadian Penyakit TB

\begin{tabular}{|c|c|c|c|c|c|c|}
\hline \multirow{3}{*}{ Kepadatan hunian } & \multicolumn{4}{|c|}{ Kejadian Penyakit TB } & \multirow{3}{*}{ Odd Ratio (OR) } & \multirow{3}{*}{$\mathbf{P}$} \\
\hline & \multicolumn{2}{|c|}{ Kasus } & \multicolumn{2}{|c|}{ Kontrol } & & \\
\hline & $\mathbf{F}$ & $\%$ & $F$ & $\%$ & & \\
\hline Tidak memenuhi syarat & 25 & 83,3 & 7 & 23,3 & 16,43 & 0,00 \\
\hline Memenuhi syarat & 5 & 16,7 & 23 & 76,7 & & \\
\hline Total & 30 & 100 & 30 & 100 & & \\
\hline
\end{tabular}




\subsection{Hubungan Lantai Rumah dengan Kejadian Penyakit TB}

Berdasarkan Tabel 8, menunjukkan bahwa 30 $\%$ kasus penghuni rumah dengan lantai rumah yang tidak memenuhi syarat kesehatan dan $70 \%$ penghuni rumah dengan lantai rumah yang memenuhi syarat kesehatan. Secara statistik terdapat hubungan yang bermakna antara kualitas lantai rumah dengan tingkat kejadian TB $(\mathrm{p}<0,05)$ dengan nilai odd ratio 2,143 . Ini berarti jika memiliki rumah dengan kualitas lantai tidak memenuhi persyaratan memiliki kemungkinan terkena penyakit TB 2,143 kali lebih besar dibandingkan dengan yaang memiliki lantai rumah memenuhi syarat. Untuk mencegah masuknya air ke dalam rumah, untuk rumah bukan panggung sebaiknya tinggi lantai $\pm 10 \mathrm{~cm}$ dari pekarangan dan $25 \mathrm{~cm}$ dari badan jalan (Adnani, 2011).

Tabel 8. Hubungan Lantai Rumah dengan Tingkat Kejadian Penyakit TB

\subsection{Besar Hubungan Sanitasi Rumah dengan Kejadian TB}

Untuk mengetahui hubungan semua variable bebas secara bersamaan dengan variable terikat dilakukan analisis multivariate menggunakan uji regresi logistik. Variabel yang bisa dimasukkan ke dalam analisis regresi logistic adalah variable yang nilainya $(p<0,25)$ yaitu: pencahayaan, kelembaban, ventilasi, dinding rumah, kepadatan hunian dan lantai rumah. Dalam penelitian ini digunakan uji regresi logistic karena dari hasil uji Hosmer-Lemeshow terhadap data hasil penelitian, didapatkan nilai chi-squarenya 4,417 dengan nilai signifikansi 0,491 . Nilai signifikansi yang didapat lebih besar dari 0,05, sehingga dapat disimpulkan bahwa data kelompok hasil observasi dikatakan fit dengan model regresi logistik.

\begin{tabular}{|c|c|c|c|c|c|c|}
\hline \multirow{3}{*}{ Ventilasi } & \multicolumn{4}{|c|}{ Kejadian Penyakit TB } & \multirow{3}{*}{ Odd Ratio (OR) } & \multirow{3}{*}{$\mathbf{P}$} \\
\hline & \multicolumn{2}{|c|}{ Kasus } & \multicolumn{2}{|c|}{ Kontrol } & & \\
\hline & $F$ & $\%$ & $F$ & $\%$ & & \\
\hline Tidak memenuhi syarat & 9 & 30 & 5 & 16,7 & 2,143 & 0,22 \\
\hline Memenuhi syarat & 21 & 70 & 25 & 83,3 & & \\
\hline Total & 30 & 100 & 30 & 100 & & \\
\hline
\end{tabular}

Tabel 9. Besar Hubungan Sanitasi Rumah dengan Kejadian Penyakit TB

\begin{tabular}{|c|c|c|c|c|c|}
\hline \multirow{2}{*}{ Variabel } & \multirow{2}{*}{ Odd Ratio (OR) } & \multirow{2}{*}{ B } & \multicolumn{2}{|c|}{$95 \% \mathrm{Cl}$ untuk OR } & \multirow{2}{*}{$P$} \\
\hline & & & Low & Upp & \\
\hline \multicolumn{6}{|l|}{ Step 1} \\
\hline Pencahayaan & 5,130 & 1,635 & 0,212 & 124,084 & 0,314 \\
\hline Kelembaban & 16,01 & 2,773 & 0,522 & 490,837 & 0,112 \\
\hline Ventilasi & 16,32 & 2,792 & 1,543 & 172,555 & 0,020 \\
\hline Dinding rumah & 0,858 & $-0,153$ & 0,111 & 6,649 & 0,884 \\
\hline Kepadatan hunian & 12,743 & 2,545 & 1,188 & 136,701 & 0,036 \\
\hline Lantai rumah & 0,187 & $-1,674$ & 0,010 & 3,630 & 0,268 \\
\hline Constant & 0,014 & $-4,296$ & & & 0,001 \\
\hline \multicolumn{6}{|l|}{ Step 2} \\
\hline Pencahayaan & 5,075 & 1,624 & 0,318 & 0,209 & 123,422 \\
\hline Kelembaban & 14,995 & 2,708 & 0,109 & 0,545 & 412,258 \\
\hline Ventilasi & 16,007 & 2,773 & 0,020 & 1,543 & 166,081 \\
\hline Kepadatan hunian & 11,677 & 2,458 & 0,019 & 1,494 & 91,285 \\
\hline Lantai rumah & 0,2 & $-1,607$ & 0,264 & 0,012 & 3,357 \\
\hline Constant & 0,014 & $-4,287$ & 0,001 & & \\
\hline \multicolumn{6}{|l|}{ Step 3} \\
\hline Kelembaban & 53,896 & 3,987 & 0,003 & 4,058 & 715,868 \\
\hline Ventilasi & 9,082 & 2,206 & 0,018 & 1,466 & 56,261 \\
\hline Kepadatan hunian & 17,506 & 2,863 & 0,004 & 2,433 & 125,945 \\
\hline Lantai rumah & 0,126 & $-2,073$ & 0,141 & 0,008 & 1,990 \\
\hline Constant & 0,017 & $-4,091$ & 0,001 & & \\
\hline \multicolumn{6}{|l|}{ Step 4} \\
\hline Kelembaban & 19,158 & 2,953 & 0,001 & 3,171 & 115,751 \\
\hline Ventilasi & 6,408 & 1,858 & 0,030 & 1,199 & 34,236 \\
\hline Kepadatan & 13,342 & 2,591 & 0,004 & 2,261 & 78,733 \\
\hline Constant & 0,24 & $-3,718$ & 0,000 & & \\
\hline
\end{tabular}


Berdasarkan Tabel 9, didapatkan hasil bahwa terdapat tiga variable bebas yang secara statistik berhubungan secara bermakna $(\mathrm{p}<0,05)$ dengan variable terikat yaitu kelembaban $(\mathrm{OR}=19,158,95 \%$ CI 3,171-115,751), ventilasi $(\mathrm{OR}=6,408,95 \% \mathrm{CI}=$ 1,199 - 34,236), kepadatan hunian (OR 13,342, 95\% $\mathrm{CI}=2,261-78,733)$

\section{SIMPULAN DAN SARAN}

\subsection{Simpulan}

Berdasarkan hasil penelitian tentang hubungan sanitasi rumah dengan kejadian penyakit tuberkulosis (TB) di Kecamatan Kuta, maka dapat disimpulkan sebagai berikut :

1. Terdapat hubungan antara sanitasi rumah dengan kejadian penyakit tuberkulosis (TB) di Kecamatan Kuta.

2. Variabel sanitasi rumah yang berhubungan dengan kejadian penyakit tuberkulosis (TB) di Kecamatan Kuta adalah : pencahayaan, kelembaban, ventilasi, dinding rumah, kepadatan hunian dan lantai rumah. Sedangkan yang tidak berhubungan dengan kejadian penyakit tuberkulosis (TB) adalah suhu .

3. Dari hasil uji statistik probabilitas orang yang menempati rumah dengan sanitasi buruk (kelembaban, ventilasi dan kepadatan hunian) di Kecamatan Kuta untuk terkena tuberkulosis (TB) adalah 97,08\%.

\subsection{Saran}

Dari hasil kesimpulan untuk dapat menurunkan kejadian tuberkulosis (TB) di Kecamatan Kuta yang berhubungan dengan sanitasi rumah, maka dapat disarankan sebagai berikut:

1. Kepada masyarakat yang tinggal di Kecamatan Kuta agar dalam membangun atau menempati rumah tinggal memperhatikan faktor sanitasi dan standar rumah sehat. Untuk dapat memenuhi standar rumah sehat maka syarat rumah sehat wajib untuk dipenuhi seperti : pencahayaan, kelembaban, suhu, ventilasi, kepadatan hunian, dinding rumah dan lantai rumah.

2. Kepada Pemerintah / SKPD terkait agar memberikan pembinaan ataupun arahan kepada masyarakat supaya dalam membangun rumah memperhatikan tata ruang serta memperhatikan rumah yang memenuhi syarat kesehatan sehingga masyarakat yang menempati rumah tersebut merasa aman, nyaman dan terhindar dari bahaya penyakit khususnya yang bersumber dari sanitasi rumah yang buruk, seperti terjadinya kasus TB.

3. Kepada Non Government Organization (NGO)/ LSM terkait supaya dapat menjadi pendamping/ memberi masukan dalam melaksanakan pembangunan/penataan perumahan khususnya masalah lingkungan dan rumah yang memenuhi standar kesehatan.

\section{DAFTAR PUSTAKA}

Adnani, 2011. Ilmu Kesehatan Masyarakat. Yogyakarta : Nuhu Medika.

Ahmad, Y.N, dan Lilis Sulistyorini. 2005. Hubungan Sanitasi Rumah Secara Fisik Dengan Kejadian ISPA Pada Balita. Jurnal Kesehatan Lingkungan I (2) : 110-119.

Depkes R.I. 2011. Strategi Nasional Pengendalian TB di Indonesia. Jakarta : Ditjen PPM - PLP.

Dewi, S. 2012.” Pengaruh Sanitasi Lingkungan Rumah Penghasilan Keluarga dan Pengendalian Terhadap Kejadian Penyakit TB Paru Pada Ibu Rumah Tangga di Puskesmas Mulyorejo Kab. Deli Serdang” (Tesis). Medan : Universitas Sumatera Utara.

Dinas Kesehatan Kabupaten Badung. 2014. Laporan Tahunan Dinas Kesehatan Kabupaten Badung2013. Mangupura : Dinas Kesehatan Kabupaten Badung.

Dinas Kesehatan Kabupaten Badung. 2015. Laporan Tahunan Dinas Kesehatan Kabupaten Badung 2014. Mangupura : Dinas Kesehatan Kabupaten Badung.

Dinas Kesehatan Kabupaten Badung. 2016. Laporan Tahunan Dinas Kesehatan Kabupaten Badung 2015. Mangupura : Dinas Kesehatan Kabupaten Badung.

Fatimah,S. 2008. Faktor Kesehatan Lingkungan Rumah yang berhubungan dengan Kejadian TB paru di Kabupaten Cilacap. Tesis : Undip Semarang.

Pemerintah Kabupaten Badung. 2015. Badung Dalam Angka 2014. Mangupura :

Pemerintah Kabupaten Badung

Sugiharto, 2004. Hubungan Kepadatan Hunian Rumah dengan Kejadian Penyakit TB Paru di Puskesmas Jenggot. Tesis : Universitas Diponegoro. Semarang

Sujana, I.K, Patra, I.M, dan Mahayan, B. I, M, 2013. Pengaruh Sanitasi Rumah Terhadap Kejadian Penyakit TB Paru di Wilayah Kerja UPT. Puskesmas Mengwi I. Jurnal Kesehatan Lingkungan 4 (1) : 93 - 98.

Wiasa, I. W, 2009. Hubungan Faktor Lingkungan Fisik Rumah dengan Kejadian TB Paru di Kabupaten Tabanan. Tesis. Universitas Air Langga Surabaya.

Yasril, Kasjono, S. H. 2009. Analisis Multivariat untuk Penelitian Kesehatan. Yogyakarta : Mitra Cendikia Offset. 